\title{
Preparation of the Precursor of Porous Alumina Particles using Immobilized Urease in Alginate Gel Templates
}

\author{
Hidero UNUMA, Yasuo HIROSE, Masayuki ITO and Kunio WATANABE \\ Department of Chemistry and Chemical Engineering, Faculty of Engineering, Yamagata University, \\ 4-3-16, Jonan, Yonezawa-shi, Yamagata 992-8510
}

\author{
アルギン酸ゲルテンプレート中の固定化酵素を利用した多孔質アルミナ粒子前駆体の合成 \\ 鵜沼英郎·広瀬保雄·伊藤正之·渡辺邦雄 \\ 山形大学工学部物質化学工学科, 992-8510 山形県米沢市城南 4-3-16
}

\begin{abstract}
This paper describes a new method to precipitate the precursor of porous alumina particles by using a porous organic matrix as the template and an enzyme as the precipitant supplier. In this work, the precursor of alumina was precipitated in urease-containing alginate gel spheres dispersed in aqueous solutions containing urea and $\mathrm{Al}^{3+}$ ion. Urease was used to hydrolyze urea so that the precursor of alumina, basic aluminum sulfate, may be precipitated selectively within the gel spheres. By burning off the gel matrices after the precipitation of the precursor, porous alumina particles were obtained. The resultant alumina particles about 1 to $2 \mathrm{~mm}$ in diameter had sharp pore size distribution profiles around 0.1 to $0.01 \mu \mathrm{m}$. The inside of the alumina particles was able to be made either hollow or filled, depending on the aging time after the precipitation of the precursor.
\end{abstract}

[Received January 13, 2004; Accepted April 27, 2004]

Key-words : Enzyme, Urease, Porous ceramics, $\mathrm{Al}_{2} \mathrm{O}_{3}$, Template

\section{Introduction}

Products of some enzymatic reactions can act as precipitants of metal ions in aqueous solutions. For example, ammonia, phosphoric acid, and oxalic acid are produced by enzymatic hydrolysis of urea, phosphate esters, and oxalate amides, respectively. By using these enzymatic reaction products, various inorganic precipitates have been prepared, such as basic aluminum sulfate, ${ }^{1), 2}$ nickel dimethylglyoximate, ${ }^{3)}$ manganese oxinate, ${ }^{4)}$ magnetite, ${ }^{5)-7)}$ hydroxyapatite, ${ }^{8), 9)}$ calcium carbonate, ${ }^{10)}$ strontium and barium carbonates, ${ }^{11)}$ calcium oxalate hydrates, ${ }^{12)}{ }^{13)}$ tin oxide hydrate, ${ }^{14)}$ hollow spheres of aluminum hydroxide, ${ }^{15)}$ and silica. ${ }^{16)}$ Some of these inorganic precipitates can be the precursors of ceramics. The use of enzymes as the "precipitant suppliers" in the preparation of the ceramic precursors brings us a number of advantages; firstly, precipitation takes place near room temperature and near neutral $\mathrm{pH}$, and secondly, the rate of the supply of the precipitant can be controlled easily. These advantages may enable us to control the size and morphology of ceramic precursors in unique ways.

In the present work, we used urease to prepare the precursor of porous alumina particles in the following way; (1) immobilization of urease in alginate gel spheres, (2) enzymatic hydrolysis of urea to supply ammonia selectively within the gel, and (3) precipitation of basic aluminum sulfate within the gel. The precursor was converted to porous alumina particles by burning off the alginate template. The morphology, specific surface area, and pore size distribution of the resultant alumina particles were characterized.

\section{Experimental procedures}

\subsection{Sample preparation}

The reagents used were purchased from Kanto Kagaku Co., Ltd., unless otherwise specified. A $20 \mathrm{~cm}^{3}$ of aqueous solution containing $0.4 \mathrm{~g}$ of ammonium alginate (Practical grade purity, Wako Pure Chemical Industries Inc.) and $2.0 \mathrm{mg}$ of urease (Nagapsin ${ }^{\circledR}, 2000 \mathrm{U} / \mathrm{g}$, Nagase Biochemicals Ltd., originated from lactobacillus fermentum) was prepared. This solution was dropwisely added to a $100 \mathrm{~cm}^{3}$ of aqueous solution containing $0.010 \mathrm{~mol}$ of aluminum sulfate hydrate, $\mathrm{Al}_{2}\left(\mathrm{SO}_{4}\right)_{3} \cdot n \mathrm{H}_{2} \mathrm{O}$, and $0.067 \mathrm{~mol}$ of urea. The amount of the hydration water in the aluminum sulfate had been determined beforehand by the thermogravimetry. It should be noted that the formulation of the solutions did not affect much the properties of the resultant alumina particles such as the appearance, specific surface area or pore size distribution. Therefore, we present here a typical formulation.

The droplets of the alginate solution transformed to opaque gel spheres about $2 \mathrm{~mm}$ in diameter within a few seconds by the cross-linking of alginate molecules with $\mathrm{Al}^{3+}$ ion. The gel spheres were left immersed in the urea/aluminum sulfate solution at $310 \mathrm{~K}$ for $24 \mathrm{~h}$ to allow the precipitation of basic aluminum sulfate to occur in the gel as described below.

While the gel spheres were left immersed in the solution, urea diffused into the gel and was hydrolyzed to ammonia (Eq. (1)). At the same time, $\mathrm{Al}^{3+}$ ion also diffused into the gel and reacted with the ammonia to precipitate as basic aluminum sulfate (Eq. (2), where basic aluminum sulfate is expressed as $\mathrm{Al}(\mathrm{OH})_{3}$ for simplification).

$$
\begin{aligned}
& \mathrm{H}_{2} \mathrm{~N}-\mathrm{CO}-\mathrm{NH}_{2}+\mathrm{H}_{2} \mathrm{O} \underset{\text { urease }}{\longrightarrow} 2 \mathrm{NH}_{3}+\mathrm{CO}_{2} \\
& \mathrm{Al}^{3+}+3 \mathrm{NH}_{3}+3 \mathrm{H}_{2} \mathrm{O} \longrightarrow \mathrm{Al}(\mathrm{OH})_{3}+3 \mathrm{NH}_{4}{ }^{+}
\end{aligned}
$$

After $24 \mathrm{~h}$ of the immersion of the gel in the solution, the gel spheres turned white due to the precipitation of $\mathrm{Al}(\mathrm{OH})_{3}$. $\mathrm{Al}(\mathrm{OH})_{3}$ content in the gel spheres increased with increasing immersion time, and it leveled off at about 60 mass $\%$ in $24 \mathrm{~h}$ as determined by the thermogravimetry. In some cases, the $\mathrm{Al}(\mathrm{OH})_{3}$-containing gel sphere particles were subsequently immersed in deionized water at $333 \mathrm{~K}$ for $5 \mathrm{~d}$ for the aging. Then, the $\mathrm{Al}(\mathrm{OH})_{3}$-containing gel sphere particles were taken out, rinsed, dried at room temperature, and heat-treated at 
873,1073 , or $1273 \mathrm{~K}$ for $2 \mathrm{~h}$ in air to burn off the alginate matrices and to convert $\mathrm{Al}(\mathrm{OH})_{3}$ to $\mathrm{Al}_{2} \mathrm{O}_{3}$. The resultant alumina particles, about 1 to $2 \mathrm{~mm}$ in diameter, were subjected to further characterization as described below.

\subsection{Characterization}

The apperance of the $\mathrm{Al}(\mathrm{OH})_{3}$-containing gel sphere particles was observed with an optical microscope. Thermogravimetry/differential thermal analysis (TG-DTA, Model TG-DTA 2000, Bruker AXS, Japan) was conducted in air up to $1400 \mathrm{~K}$ at a heating rate of $10 \mathrm{~K} / \mathrm{min}$. Crystalline phases present in the heat-treated particles were examined on an X-ray diffraction analyzer (XRD, Model RINT 2200, Rigaku). Specific surface area was measured by the nitrogen adsorption method (Model FlowsorbII-2300, Shimadzu) and the pore size distribution was analyzed by the mercury porosimetry (Model Autoscan-60, Yuasa Ionics).

\section{Results and discussion}

Figure 1 shows the optical micrographs of the outside and inside of the $\mathrm{Al}(\mathrm{OH})_{3}$-containing gel sphere particles before heat treatments. The non-aged gel particles were about $2 \mathrm{~mm}$ in diameter and the inside was hollow as shown in the Figs. 1 (a) and (b). On the other hand, aged gel sparticles were about $1 \mathrm{~mm}$ in diameter and the inside was filled as shown in the Figs. $1(\mathrm{c})$ and (d). The shape and size of the particles did not change after the burning off the alginate matrices.

A mechanism of the formation of the hollow particles is proposed as follows. As described earlier, urea is enzymatically hydrolyzed in the gel spheres to form ammonia, and it reacts with $\mathrm{Al}^{3+}$ to form $\mathrm{Al}(\mathrm{OH})_{3}$. If the rate of the hydrolysis of urea is higher than that of the diffuse-in of $\mathrm{Al}^{3+}$ ion, ammonia and $\mathrm{Al}^{3+}$ ion would encounter in the vicinity of the surfaces of the gel spheres, and a "shell" of $\mathrm{Al}(\mathrm{OH})_{3}$ would be formed near the gel surface. Once the $\mathrm{Al}(\mathrm{OH})_{3}$ shell is formed, the diffuse-in of $\mathrm{Al}^{3+}$ would be slowed down further, causing the thickening the $\mathrm{Al}(\mathrm{OH})_{3}$ shell. That would lead to the formation of the hollow particles.

The formation of the filled particles would be accounted for as follows; when the hollow particles are aged in water, the Ostwald-type ripening via dissolution-reprecipitation would take place, and $\mathrm{Al}(\mathrm{OH})_{3}$ precipitate would diffuse to the inside of the gel spheres.

The use of enzymatic hydrolysis of urea was essential in order to precipitate alumina precursors selectively within the gel spheres. To confirm the necessity of the use of urease, we made the following preliminary experiment; ammonium alginate was dissolved in ammonia water, and the solution was dropwisely added to an aluminum sulfate solution. In this case, the formation of $\mathrm{Al}(\mathrm{OH})_{3}$ took place too quickly for spherical gel spheres to form. The shape of the resultant gel was very irregular and never became spherical. The amount of the $\mathrm{Al}(\mathrm{OH})_{3}$ was also smaller than that obtained by the present technique.

Figure 2 shows the TG-DTA profile of $\mathrm{Al}(\mathrm{OH})_{3}$-containing gel sphere particles. A gradual weight loss accompanied with endothermic responses is seen below $500 \mathrm{~K}$, which should be attributed to the evaporation of adsorbed water, dehydration of basic aluminum sulfate, and thermal decomposition of alginate matrix. Then, a broad exothermic event accompanied with a gradual weight loss is observed in a range from 500 to $1100 \mathrm{~K}$, which may be due to the combustion of the organic residue. A small weight loss accompanied with a sharp endothermic response around $1200 \mathrm{~K}$ should be assigned to the dissociation of sulfate ion from basic aluminum sulfate. No weight change is seen above $1250 \mathrm{~K}$. Since the ceramic content
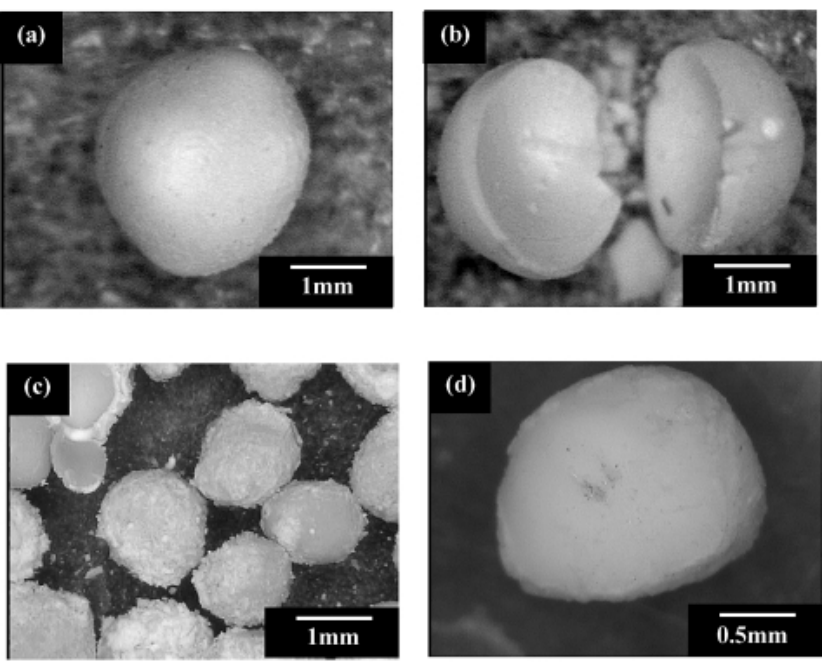

Fig. 1. Optical micrographs of the outside ((a) and (c)) and inside ( (b) and (d)) of the alginate gel sphere particles containing alumina precursor. Particles shown in (a) and (b) were not aged while those in (c) and (d) were aged in deionized water at $333 \mathrm{~K}$ for $5 \mathrm{~d}$.

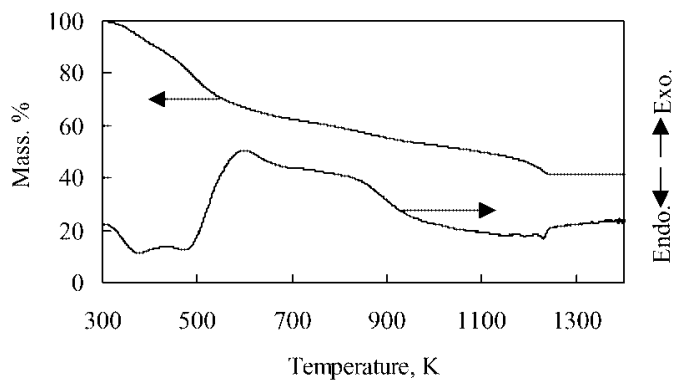

Fig. 2. TG-DTA profile of the alginate gel sphere particles containing alumina precursor.

in this sample is about 40 mass $\%$ as $\mathrm{Al}_{2} \mathrm{O}_{3}$, the content of basic aluminum sulfate $\left(\right.$ as $\left.\mathrm{Al}(\mathrm{OH})_{3}\right)$ in the as-precipitated particles is calculated to be about 60 mass $\%$.

Figure 3 shows the evolution of the crystalline phases upon heat treatment. Although no distinct diffraction peak was observed after a heat treatment at $873 \mathrm{~K}$, the samples crystallized into $\gamma$-and $\alpha$-alumina after the heat treatments at 1073 and $1273 \mathrm{~K}$, respectively. This crystallization behavior is commonly found in the crystallization of basic aluminum sulfate. ${ }^{1)}$

Figure 4 shows the pore size distribution and specific surface area of the alumina particles. Hollow particles (shown in (a)) have pores about $0.1 \mu \mathrm{m}$ in pore diameter, while filled particles (shown in (b)) have pores about $0.01 \mu \mathrm{m}$ in pore diameter. Both particles have quite sharp pore size distribution profiles. All the particles have specific surface area around $100 \mathrm{~m}^{2} / \mathrm{g}$, which slightly decreases after the heat treatment at $1273 \mathrm{~K}$. It would be reasonable to consider that these pores had been templated by the framework of the alginate gel.

\section{Conclusions}

Precursor of porous alumina particles was prepared using immobilized urease in alginate gel spheres. The precipitant, ammonia, was supplied through enzymatic hydrolysis of urea 


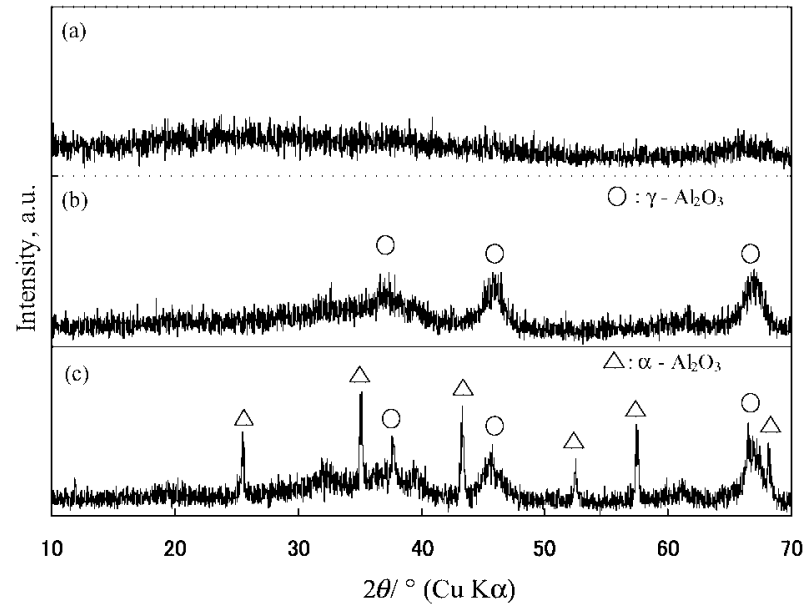

Fig. 3. XRD profiles of alumina particles heat-treated at (a) 873, (b) 1073 , and (c) $1273 \mathrm{~K}$ for $2 \mathrm{~h}$.

within the gel spheres. By buring off the alginate matrices after the precipitation of the precursor, porous alumina particles were obtained. The inside was able to be made either hollow or filled by changing the aging time after the precipitation of the precursor. The resultant alumina particles, 1 to $2 \mathrm{~mm}$ in diameter, had sharp pore size distribution profiles around 0.1 and $0.01 \mu \mathrm{m}$ in pore diameter, reflecting the template effect of the alginate gel matrices.

\section{References}

1) Unuma, H., Kato, S., Ota, T. and Takahashi, M., Adv. Powder Technol., Vol. 9, pp. 181-190 (1998).

2) Kara, F. and Sahin, G., J. Eur. Ceram. Soc., Vol. 20, pp. 689-694 (2002).

3) Hikime, S., Yoshida, H. and Taga, M., Talanta, Vol. 14, pp. 1417-1422 (1967).

4) Hikime, S., Yoshida, H., Taga, M. and Taguchi, S., Talanta, Vol. 19, pp. 569-572 (1972).

5) Hamaya, T. and Horikoshi, K., Agric. Biol. Chem., Vol. 53, pp. 1989-1990 (1989).

6) Hamaya, T. and Horikoshi, K., Agric. Biol. Chem., Vol. 53, pp. 851-852 (1989).

7) Hamaya, T., Takizawa, T., Hidaka, H. and Horikoshi, K., $J$. Chem. Eng. Jpn., Vol. 26, pp. 223-224 (1993).

8) Banks, E., Nakajima, S., Shapiro, L. C., Tilevitz, O., Alonzo, J. R. and Chianelli, R. R., Science, Vol. 198, pp. 1164-1166 (1977).

9) Doi, Y., Horiguchi, T., Moriwaki, Y., Kitago, H., Kajimoto, T.
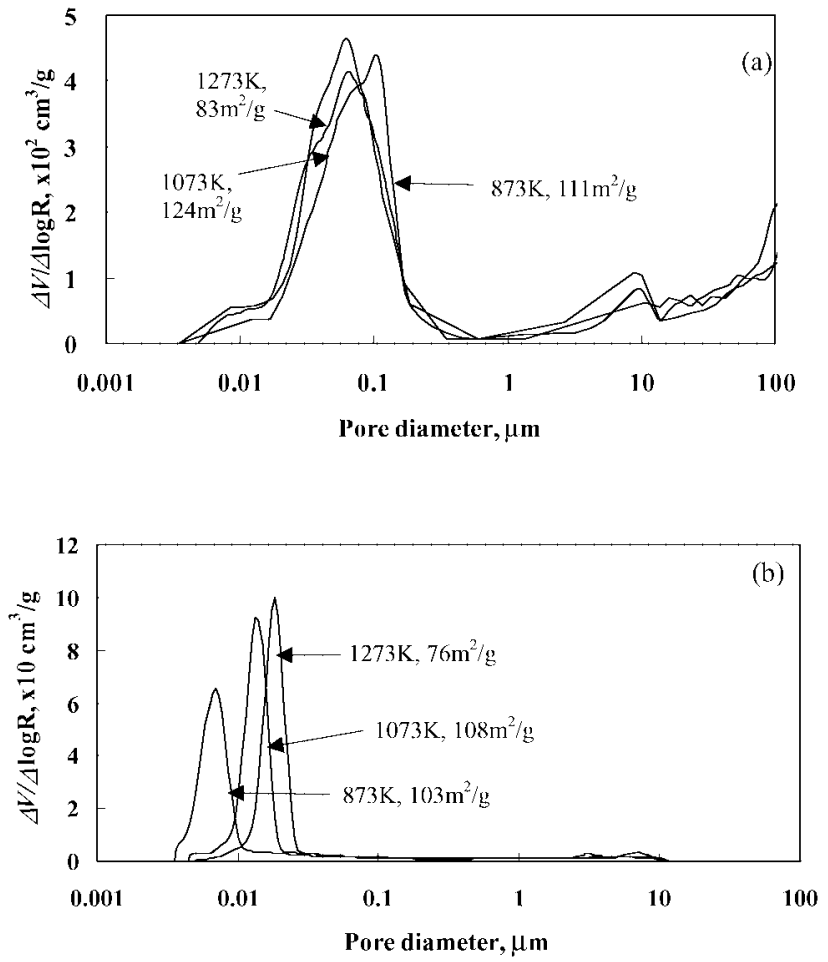

Fig. 4. Pore size distribution and specific surface area of (a) hollow and (b) filled alumina particles heat-treated at various temperatures.

and Iwayama, Y., J. Biomed. Mater. Res., Vol. 31, pp. 43-49 (1996).

10) Sondi, I. and Matijević, E., J. Colloid Interfa. Sci., Vol. 238, pp. 208-214 (2001).

11) Sondi, I. and Matijević, E., Chem. Mater., Vol. 15, pp. 1322-1326 (2003).

12) Kato, S., Ota, T., Takahashi, M. and Unuma, H., Ceram. Trans., Vol. 112, pp. 53-58 (2001).

13) Kato, S., Unuma, H. and Takahashi, M., Adv. Powder Technol., Vol. 12, pp. 493-505 (2001).

14) Kato, S., Unuma, H., Ota, T. and Takahashi, M., J. Am. Ceram. Soc., Vol. 83, pp. 986-988 (2000).

15) Kato, S., Makino, T., Unuma, H. and Takahashi, M., J. Ceram. Soc. Japan, Vol. 109, pp. 369-371 (2001).

16) Buisson, P., El Rassy, H., Maury, S. and Pierre, A. C., J. Sol-Gel Sci. Technol., Vol. 27, pp. 373-379 (2003). 